\title{
Neotypus pusillus Gregor, 1940 (Hymenoptera, Ichneumonidae) endoparasite of Maculinea nausithous (Bergsträsser, 1779) (Lepidoptera, Lycaenidae): new data on distribution in Poland with remarks on its biology
}

\author{
Anna M. StankIEWICZ*, Marcin SieleZniEW** \& Janusz SaWonIEWICZ*** \\ *Laboratory of Social and Myrmecophilous Insects, Museum and Institute of Zoology, Polish Academy of Sciences, \\ Wilcza 64,00-679 Warszawa, Poland; e-mail: ams@miiz.waw.pl \\ **Department of Applied Entomology, SGGW - Warsaw Agriculture University, Nowoursynowska 166, 02-787 \\ Warszawa, Poland; e-mail: sielezniew@alpha.sggw.waw.pl \\ ***Department of Invertebrate Zoology, Institute of Biology, University of Bialystok, ul. Świerkowa 20B, 15-950 \\ Bialystok, Poland; e-mail: aptesis@uwb.edu.pl
}

\begin{abstract}
Neotypus pusillus in Europe is a parasite of the obligatory myrmecophilous lycaenid butterfly Maculinea nausithous. It was recorded for the last time in Poland at the beginning of the 20th century on a few sites in Lower Silesia and on one site near Poznań. During the present studies we found Neotypus pusillus in two other regions: in Polesie (eastern Poland) and in Upper Silesia. On both sites adult females were observed ovipositing on flowerheads of Sanguisorba officinalis L. with $M$. nausithous caterpillars inside. Additionally we reared two males from parasitized pupae. N. pusillus is probably more widespread in Poland but restricted to big populations of M. nausithous. Some remarks about the biology and ecology of the parasitoid are included in the paper.
\end{abstract}

Key words: Hymenoptera, Ichneumonidae, Neotypus pusillus, parasitoid, Maculinea nausithous, endangered species, myrmecophily

\section{INTRODUCTION}

Ichneumonidae is the biggest family of Hymenoptera, consisting of about 22,000 described species (Yu \& Horstmann 1997). About 3,000 of Ichneumonidae species probably occurs in Poland and they are among poorest known insects, taking into account their biology and distribution (Sawoniewicz 2002). The larvae of almost all Ichneumonidae are parasitoids of different stages of insects with complete development, although a few species use adult spiders as hosts (Araneida) or their eggs and a few representatives may parasite Pseudoscorpionida eggs kept in a membranous sac attached to the female (Wahl 1993).

Ichneumoninae, with its 373 genera, is the second largest subfamily of Ichneumonidae and is widespread across the world (Wahl 1993). All individuals of this subfamily are endoparasitoids specializing in Lepidoptera (Hinz 1983). Two types of parasitation habits have been distinguished. Many Ichnemoninae species are idiobionts i.e. adults kill or paralyze caterpillars, which are then eaten immediately by their larvae. The second group encompasses koinobionts, which parasite active hosts, allowing them to continue development and often even to pupate. Parasitoids then reach maturity and leave the dying caterpillars or pupae. The koinobiontic genus Neotypus Förster, 1868 is represented in Europe by four species (Selfa \& Schönitzer 1994): N. coreensis Uchida, 1930, N. nobilitator (Gravenhorst, 1807), N. pusillus and $N$. intermedius Mocsáry, 1883. All except the last have been recorded in Poland.

Neotypus pusillus Gregor, 1940 (syn. Ichneumon melanocephalus Gmelin, 1790 (preocc.) and Neotypus melanocephalus ssp. pusillus Gregor, 1940) (Selfa \& Schönitzer 1994) has not been found in Poland for over seventy years. Knowledge on its distribution and ecology 
remains very fragmentary, as is the case with many other Ichneumonid species. However the interest in $N$. pusillus's life-history and behavior is still increasing due to its specific, parasitic association with Maculinea nausithous - an obligatorily myrmecophilous butterfly, which is endangered in Europe (van Swaay \& Warren 1999). In the present studies we gathered available data about the distribution of $N$. pusillus, including information about former and newly discovered sites in Poland.

\section{RELATION OF NEOTYPUS PUSILLUS TO MACULINEA NAUSITHOUS}

Females of the genus Neotypus search for caterpillars which are still feeding on their host plants (Thomas \& Elmes 1993). They parasitise on larvae of various Lycaenidae species (Townes et al. 1965, Sime \& Wahl 2002). The first identification of a host of $N$. pusillus was by Torka (1928) who described it from Lycaena arcas, an old synonym of Maculinea nausithous. No other hosts have been mentioned for $N$. pusillus. Related species (Yu 1999) like $N$. nobilitator parasitizes on Everes argiades (Pallas, 1771), E. lacturnus (Godart, 1824), Lampides boeticus (Linnaeus, 1767), Pseudozizeeria maha (Kollar, 1884), Zizina otis (Fabricius, 1787) and for $N$. coreensis the only known host is Niphanda fusca (Bremer \& Grey, 1852).

M. nausithous inhabits the Palaearctic region and ranges from northern Spain to the Ural Mts. and to the Caucasus (Wynhoff 1998). The butterfly is in danger of extinction in Europe and it is listed in Appendix II of the Bern Convention. Poland is the only European country where its status is estimated as 'stable' (van Swaay \& Warren 1999). M. nausithous still occurs on numerous sites mainly in the central and southern part of the country (Buszko 1997).

Females of $M$. nausithous are on the wing in July and August and lay eggs on flowerheads of Sanguisorba officinalis. Young larvae feed on flowers and seeds for about three weeks. During this time they develop quickly through three instars, but they only about $1-2 \%$ of their final body weight. At the beginning of the fourth instar they drop to the ground and wait for adoption by workers of Myrmica Latreille, 1804 ants (Thomas 1995). Healthy as well as parasited larvae spend about 9-10 months in the ant colonies, where they prey on the ant brood. In early summer they pupate in the upper chambers of nests from which adult butterflies or parasitoids emerge after a few weeks. The relationship between $M$. nausithous and Myrmica ants is highly specific. In Poland, as in the whole of Europe, they survive only in $M$. rubra (Linnaeus) nests (Thomas et al. 1989, Stankiewicz \& Sielezniew 2002).

\section{THE OCCURRENCE OF NEOTYPUS PUSILLUS IN POLAND}

N. pusillus was recorded in Poland for the first time in Lower Silesia (Duszniki Zdrój and Kudowa Zdrój) at the beginning of XIX century (Gravenhorst 1829). A hundred years later it was observed again in this region by Hedwig (1927) on sites situated in Wrocław-Leśnica, Niemcza, Kudowa Zdrój, Stronie Śląskie, Kotlina Kłodzka and in the vicinity of Strzegom. Additionally Torka (1928) found it at Prudnik and in Poznań, where he had observed an overwintering female, but in the spring he did not notice any individuals.

Specimens collected in the Białystok area and classified as N. pusillus (Sawoniewicz 1974) were misidentified and in fact belong to $N$. coreensis species.

\section{NEW SITES OF NEOTYPUS PUSILLUS}

During the present studies individuals of $N$. pusillus were recorded on two sites in the eastern and southern part of Poland (Fig. 1).

Kosyń ( $51^{\circ} 23^{\prime} \mathrm{N} / 23^{\circ} 34^{\prime} \mathrm{E}$, UTM FB 89, $160 \mathrm{~m}$ a.s.l.) is situated in Sobibór Landscape Park, Lubelska Upland, eastern Poland. The heterogeneous habitat there consists of Molinion and 
Filipendulion vegetation mixed with Salicetum pentandro-cinerae, some parts are covered by Caricion fuscae fens. Flowering Sanguisorba are scattered and their density is about $0.5 \mathrm{~m}^{2}$.

In the first days of August 2001, a few females of $N$. pusillus were seen ovipositing into $S$. officinalis flowerheads. Dissections revealed the presence of 2-3 Maculinea larvae feeding inside each flowerhead. Apart from M. nausithous we found caterpillars of its close relative, $M$. teleius (Bergsträsser, 1779). There were no nests of $M$. rubra ants in the vicinity of the plants. On the site two $N$. pusillus females were collected.

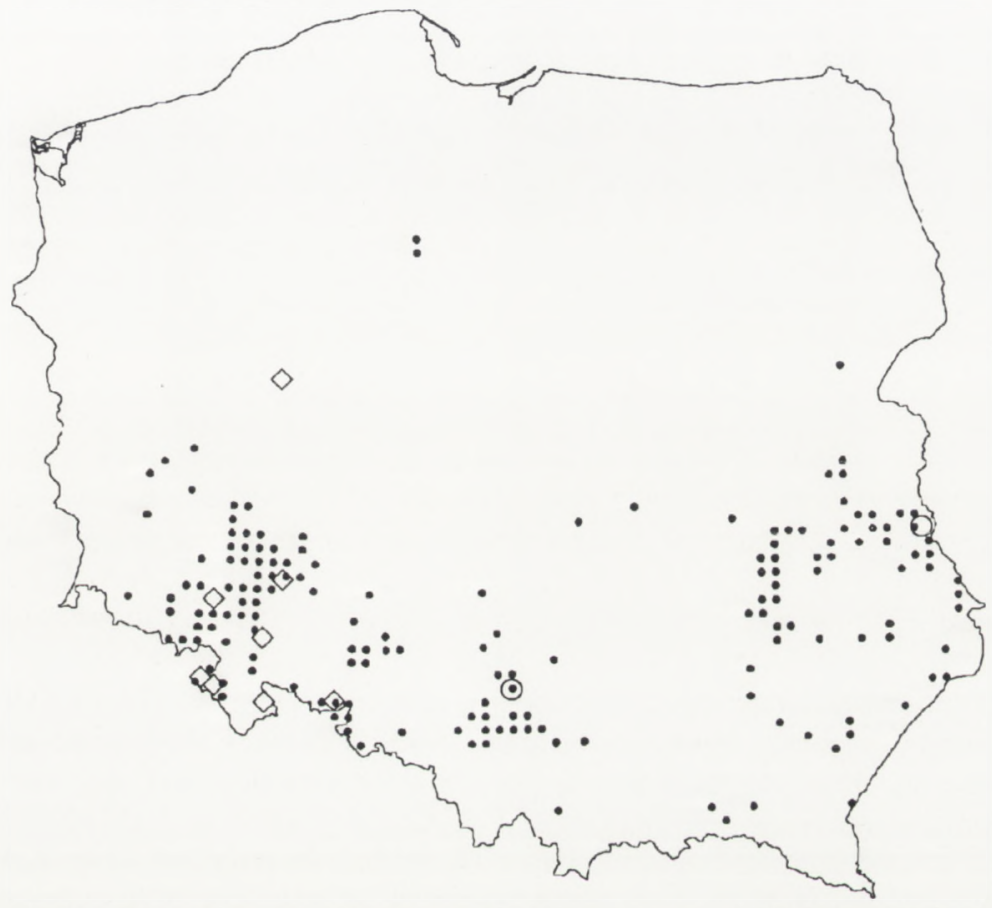

Fig. 1. Past and present sites of Neotypus pusillus on the background of the distribution of its host Maculinea nausithous: $\diamond-$ sites of $N$. pusillus from the beginning of 20th century (Hedwig 1927, Gravenhorst 1829, Torka 1928), $\mathrm{O}$ - new sites of $\mathrm{N}$. pusillus recorded during the present studies, $\bullet-10 \mathrm{~km}$ UTM squares with M. nausithous (Buszko 1997)

In early August 2002 some females of the parasitoid were observed again in another part of the site, about $0.5 \mathrm{~km}$ away. In July 2003 nests of $M$. rubra were searched, but from several dozens of $M$. nausithous examined, pupae only once turned out to be parasited and a male of $N$. pusillus emerged.

Głazówka near Łazy (50²4'N/19²2'E, UTM CA 88, $330 \mathrm{~m}$ a.s.l.) is situated on the borderland between Krakowsko-Częstochowska Upland and the Silesian Upland. The habitat encompasses Molinion meadows and their successional stages towards Filipendulion vegetation. Overgrowing is a result of abandonment of former hay meadows. S. officinalis is quite abundant on the site, in some parts it occurs in high density.

In July 2003 an infested pupa was found in a M. rubra nest, from which after 2 weeks the male of the parasitoid emerged. The same year in August a lot of females were observed laying eggs on S. officinalis (Fig. 2). Inside the flowerheads, similarly to Kosyń, the larvae of two sympatric species: $M$. nausithous and $M$. teleius were feeding. Furthermore a lot of parasitoid adults were recorded feeding nectar on Apiaceae flowers. 


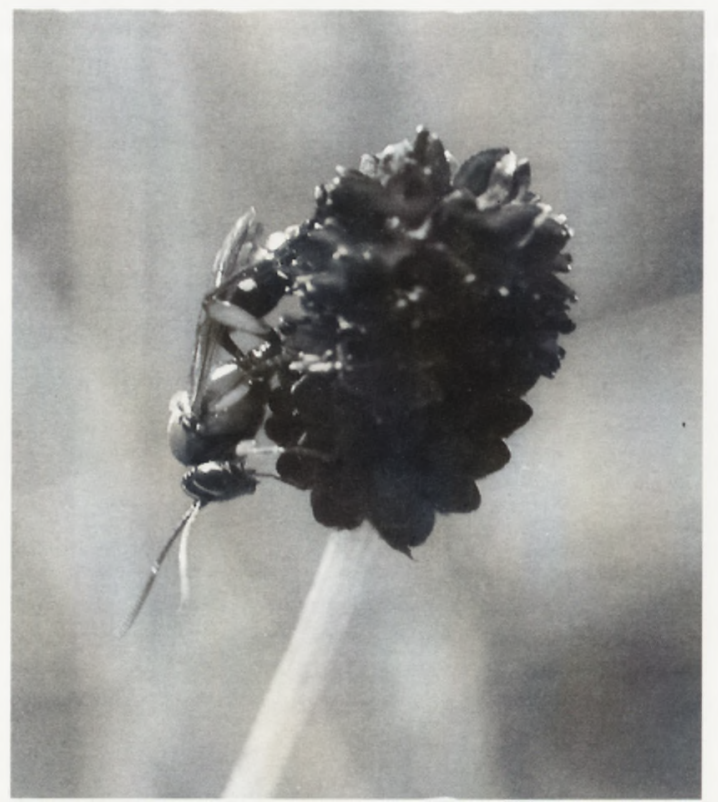

Fig. 2. A female of Neotypus pusillus ovipositing to a Maculinea nausithous larva feeding inside a Sanguisorba officinalis flowerhead

\section{DISCUSSION}

At present Maculinea nausithous is the only known host for N. pusillus (Yu 1999), which is regarded as highly specific (Thomas \& Elmes 1993). However there is no unquestionable evidence that it is a monophagous species. Until now the parasitoid has only been recorded on a few sites in the western and northern part of the country. The new locality of N. pusillus in Poland found at Kosyń is also the farthest east. On the site the parasitic wasp seems to be very rare, probably as a result of the very small density of $M$. rubra nests in comparison to other Myrmica ants. Females of $M$. nausithous do not really have the ability to detect $M$. rubra nests (Thomas \& Elmes 2001, Stankiewicz \& Sielezniew 2002) and M. nausithous caterpillars, also those parasitized by $N$. pusillus, are adopted by unsuitable ant species. In many cases $N$. pusillus females infected $M$. nausithous larvae on plants, which grew in a completely unsuitable area lacking nests of $M$. rubra, where neither butterflies nor parasitoids could reach maturity.

At Głazówka detailed studies of ant species composition and density of their nests were not performed, but preliminary observations indicate that $M$. rubra occurs more frequently than at Kosyń, providing $M$. nausithous as well as $N$. pusillus populations with better conditions. It is also likely that $N$. pusillus is still present on some of the sites where it was discovered for the first time and in other parts of the Lower Silesian region with strong populations of $M$. nausithous. The only exception is the Poznan site where $M$. nausithous no longer occurs, and there have been no records of this species in the Wielkopolska region for the last decades (Buszko \& Nowacki 2000). N. pusillus is probably more widespread in the southern part of the country, in Upper Silesia and in Lubelska Upland, where $M$. nausithous has a close range of distribution. However we have excluded the probability of the presence of $N$. pusillus on isolated sites near Chełmno in northern Poland, as it was not noticed during intensive behavioural studies of M. nausithous in August 2000 (Stankiewicz 2001). 
Sites where both $M$. nausithous and $N$. pusillus coexist are very rare since this unique relation requires specific habitat parameters, first of all density and spatial distribution of $S$. officinalis plants and $M$. rubra nests. During its life cycle the parasitoid is exposed to some limiting factors. Females of $N$. pusillus have to parasitize as many butterfly larvae as they can but an immature parasitoid although protected within a host has no influence on its survival. Inside a single flowerhead up to 30 eggs of $N$. nausithous may be found (Stankiewicz \& Sielezniew 2002) because the presence of eggs does not deter females from further ovipositions into a bud. Additionally, flowerheads are often shared with eggs and larvae of $M$. teleius. Food competition as well as a possible cannibalistic tendency, as, for example, that exhibited by $M$. arion, on overcrowded plants (Thomas 1980), eliminates smaller and weaker caterpillars. Our additional observations have shown that females of $N$. pusillus lay eggs into $S$. officinalis flowerheads bearing only a few caterpillars, thereby increasing the chances of survival of the parasitoid offspring. Infected caterpillars normally develop during the endophytic phase and then their chances for adoption by Myrmica ants are probably the same as in the case of healthy Maculinea larvae. However this is a "bottleneck" in the butterfly lifecycle because of the highly specific relation with $M$. rubra ants, whose nests can be very sparse, as in Kosyń.

Moreover, many larvae of both Maculinea species can reach the same M. rubra nest and compete for food resources. Consequently it is possible that no individual receives enough food for effective growth and/or ant colonies abandon their nests leaving Maculinea inside (Thomas \& Elmes 1998). There are no data on the hypothesis that infection by $N$. pusillus influences the survival of the $M$. nausithous caterpillar.

The main growth and the metamorphosis of the parasitoid occur presumably just within the pupa of the host. Adults of the parasitic wasp emerge at the same time as adults of $N$. nausithous. An interesting issue for research would be the behaviour of $N$. pusillus inside an ant colony after its eclosion from the pupa of $M$. nausithous. Ichneumon eumerus Wesm. parasiting Maculinea rebeli secretes special chemicals inducing mutual aggression in the ant workers. It enables safe departure from the nest for newly-emerged wasps and it also helps females of I. eumerus with penetration of nests during oviposition, which occurs later than in the event of $N$. pusillus (Thomas \& Elmes 1993, Thomas et al. 2002).

Apparently not every population of $M$. nausithous can support a viable population of the parasitoid. In Europe such localities are very rare and $N$. pusillus is probably more endangered than its lepidopteran host. M. nausithous as well as other Maculinea butterflies thrive in Europe only in extensively used grassland habitats (Thomas 1995). This kind of land management is regarded as barely profitable nowadays and it is becoming rare in Poland too. Special conservation efforts are urgently needed to protect the unique butterfly - ant - parasitoid system.

\section{ACKNOWLEDGMENTS}

The authors thank to the referees, dr Ewa Skibińska, dr Sergey Belokobylskij and dr Jeremy A. Thomas, for their valuable comments and suggestions regarding the manuscript. Dr Jeremy A. Thomas also kindly made linguistic improvements.

\section{REFERENCES}

BuszKo J. 1997. A distribution Atlas of Butterflies in Poland 1986-1995. Turpress, Torun. 170 pp.

Buszko J. \& NowaCki J. 2000. The Lepidoptera of Poland. A distributional checklist. Poznań-Toruń, Pol. Entomol. Monogr. 1: 1-176.

GRAvenhorst J. L. C. 1829. Ichneumonologia Europaea. Pars I. Generalia de ichneumonidibus, ichneumones, supplementa, indices et tabulas duas lapidi incisas. Sumptibus Auctoris, Vratislaviae, $827 \mathrm{pp}$.

HEDWIG K. 1927. Verzeichnis der bisher in Schlesien aufgefundenen Hymenopteren. V. Ichneumonidae. Zeit. Ent., Breslau, 15: 2-16. 
HINZ R. 1983. The biology of the European species of the genus Ichneumon and related species (Hymenoptera: Ichneumonidae). Contrib. Amer. Ent. Inst. 20: 151-152.

SAWONIEWICZ J. 1974. Gąsienicznikowate (Ichneumonidae, Hymenoptera) odwiedzające kwiaty goryszu Peucedanum oreoselinum L. (Umbelliferae). Folia Forest. Polonica, A, 21 (1973): 43-78.

SAWONIEWICZ J. 2002. Hymenoptera parasitica (Terebrantes) Błonkówki pasożytnicze (Owadziarki) In: GŁowACIŃSKI Z. (ed.), Czerwona lista zwierząt ginących i zagrożonych w Polsce, pp.51-53. Instytut Ochrony Przyrody PAN, Kraków, 155 pp.

SELFA J. \& SCHÖNITZER K. 1994. Taxonomy of European species of Neotypus Förster, [1869] with a key for their identification (Hymenoptera, Ichneumonidae, Ichneumoninae, Listrodomini). Entomofauna 15: 469-479.

SIME K. R. \& WAHL D. B. 2002. The cladistics and biology of the Callajoppa genus-group (Hymenoptera: Ichneumonidae, Ichneumoninae). Zool. J. Linn. Soc. 134: 1-56.

STANkIEWICZ A. 2001. Porównanie biologii i etologii dwóch sympatrycznych gatunków motyli: modraszka telejusa (Maculinea teleius) i modraszka nausitousa (M. nausithous). MSc thesis. SGGW - Warsaw Agriculture University, $67 \mathrm{pp}$.

Stankiewicz A. \& Sielezniew M. 2002. Host specificity of Maculinea teleius BgSTR. and M. nausithous BgSTR. (Lepidoptera: Lycaenidae): The new insight. Ann. Zool. 53(3): 403-408.

THOMAS J. A. 1980. Why did the large blue become extinct in Britain? Oryx 15: 243-247.

ThOMAS J. A. 1995. The ecology and conservation of Maculinea arion and other European species of large blue butterfly. In: PUllin A. S. (ed.), Ecology and Conservation of Butterflies, pp. 180-197. Chapman \& Hall, London, 363 pp.

Thomas J. A. \& Elmes G. W. 1993. Specialized searching and the hostile use of allomones by a parasitoid whose host, the butterfly Maculinea rebeli, inhabits ant nests. Anim. Behav. 45: 593-602.

Thomas J. A. \& Elmes G. W. 1998. Higher productivity at the cost of increased host-specificity when Maculinea butterfly larvae exploit ant colonies through trophallaxis rather than by predation. Ecol. Entomol. 23: 457-464.

Thomas J. A. \& ElmES G. W. 2001. Food plant niche selecion rather than the present of ant nests explains oviposition patterns in the myrmecophilous butterfly genus Maculinea. Proc. R. Soc. London, B, 268: 471-477.

Thomas J. A., Elmes G. W., Wardlaw J. C. \& WoyciechowsKi M. 1989. Host specificity among Maculinea butterflies in Myrmica ant nests. Oecologia 79: 425-457.

Thomas J. A., Knapp J. J., Akino T., Gerty S., Wakamura S., Simcox D. J., Wardlaw J. C. \& Elmes G. W. 2002. Parasitoid secretions provoke ant warfare. Nature 417: 505-506.

TORKA V. 1928. Ichneumoniden Oberschlesiens. Internationale Entomologische Zeitschrift, Guben, 21: $411-414$.

TOWNES H., MOMOI S. \& TOWNES M. 1965. A catalogue and reclassification of eastern Palearctic Ichneumonidae, $661 \mathrm{pp.}$

VAN SWAAY C. A. M. \& WARREN M. 1999. Red data book of European butterflies (Rhopalocera). Nature and Environment, No 99. Council of Europe Publishing, Strasbourg, 260 pp.

WAHL D. B. 1993. Familly Ichneumonidae. In: Goulet H. \& HuBER J.T. (eds). Hymenoptera of the world: An identification guide to families. pp. 395-448, 478-509. Agriculture Canada Publication, Ottawa, 668 pp.

WYNHOFF I. 1998. The recent distribution of the European Maculinea species. J. Ins. Cons. 2: 15-27.

YU D. S. 1999. Interactive catalogue of world Ichneumonidae 1998 [CD-ROM]. Taxapad: Scientific names for information management. Natural History Musuem, London, UK.

YU D. S. \& Horstmann K. 1997. Catalogue of the World Ichneumonidae (Hymenoptera). Part 1 and 2. Mem. Amwer. Ent. Inst. 58: 1-1558.

\section{STRESZCZENIE}

[Tytuł: Neotypus pusillus Gregor, 1940 (Hymenoptera, Ichneumonidae) endoparazytoid modraszka nausitousa Maculinea nausithous (Bergsträsser, 1779) (Lepidoptera, Lycaenidae): nowe dane o rozmieszczeniu w Polsce wraz z informacjami o jego biologii]

Praca zawiera pierwsze od ponad 70 lat dane na temat występowania w Polsce Neotypus pusillus - pasożyta myrmekofilnego motyla Maculinea nausithous zagrożonego w Europie wyginięciem. $N$. pusillus był dotychczas wykazany jedynie z paru stanowisk na Dolnym Śląsku oraz jednego z okolic Poznania. W czasie obecnych badań znaleziono go w dwóch innych regionach: na Polesiu i na Górnym Śląsku. Na stanowiskach obserwowane były samice składające jaja do kwiatostanów Sanguisorba officinalis ze znajdującymi się w środku gąsienicami $M$. nausithous. Ponadto wyhodowano dwa samce z poczwarek motyla. $N$. pusillus jest prawdopodobnie bardziej rozprzestrzeniony w Polsce, ale ograniczony do du żych populacji $M$. nausithous. W pracy zawarte są również uwagi na temat biologii i ekologii tego gatu nku. 